\title{
Exploring Strategies to Optimize the Collection of Zakat on Shares in Indonesia
}

\author{
Sheila Amalia ${ }^{1}$
}

\begin{abstract}
This research aims to analyze the priorities of the problems in the collection of zakat on shares, and then identify the best solutions and strategies to enhance the collection performance. The employed method is Analytic Network Process (ANP). The result shows that there are three main problems in collecting zakat on shares: (1) The absence of government enforcement, (2) No integrated services to the zakat institutions (OPZ), and (3) The less understanding of investors about zakat on shares. As for the solutions by priority are: (1) Providing integrated services to the OPZ, (2) Make a collaboration to the securities, and (3) To increase the awareness to pay out zakat on shares. Meanwhile, the best strategies by priority are (1) Regulatory approach from Indonesian Stock Exchange to securities, (2) Zakat payroll system on shares, and (3) Campaign in the television.
\end{abstract}

Keywords: Zakat, Shares, ANP

Abstrak. Penelitian ini bertujuan untuk menganalisa prioritas permasalahan dalam penghimpunan zakat saham, kemudian mengidentifikasi solusi dan strategi terbaik untuk meningkatkan kinerja penghimpunan. Metode yang digunakan adalah Analytic Network Process (ANP). Hasilnya menunjukkan bahwa ada tiga permasalahan utama dalam penghimpunan zakat saham: 1) Tidak ada paksaan dari pemerintah, 2) Tidak ada pelayanan terintegrasi dengan Organisasi Pengelola Zakat (OPZ), dan 3) Lemahnya pemahaman investor tentang zakat saham. Adapun prioritasi solusi adalah: 1) Menyediakan pelayanan terintegrasi dengan OPZ, 2) Membuat kolaborasi dengan perusahaan sekuritas, dan 3) Meningkatkan kesadaran untuk menunaikan zakat saham. Sementara itu, strategi terbaik berdasarkan prioritas adalah: 1) Pendekatan regulasi dari Bursa Efek Indonesia kepada Sekuritas, 2) Pembuatan system payrol zakat saham, dan 3) Kampanye di televisi.

Kata kunci: Zakat, Saham, ANP

${ }^{1}$ STEI Tazkia, Indonesia|syidatan@gmail.com 


\section{Introduction}

Zakat on investment is zakat of profit from the investment. Zakat on investment in the term of Fiqh is also called as zakat "Al-mustaghillat". Shares is one type of investment that is growing in the sequence number three after gold and property (based on a survey by yuswohady, 2015). The number of moslem investors significantly increases as shown by the increase of Indonesia's Sharia Stock Index (ISSI).

Shares and securities (bonds) as a proof of the value of a company's wealth is one of the objects of zakat listed in the literature of contemporary zakat fiqh. Shares are one of the sources of wealth which it's obligated when it reaches haul and nishab (Qardhawy, 2002). The $1^{\text {st }}$ International Congress on zakat in Kuwait in 1404 H (1993 M) has established the obligation of zakat on shares.

Studies on zakat shares are still limited to its legality and how the mechanism to calculate it as well as the accounting treatment to the zakat shares. Mawar and Edy (2015), Nurjanah (2011), Rahman (2015), and Aristoni and Abdullah (2015) discussed zakat on shares from the Islamic law's perspective, while Islahi and Obaidillah (2004) explored some unsettled issues in it. In addition, Hamat et al. (2017) studied the calculation of zakat on shares and its accounting. On the other hand, some papers studied the problems and solutions in the implementation of zakat in general; Mujiatun (2016), Paizin (2014) Hayati (2012). Unfortunately, they did not focus on the problems and solution in zakat on shares.

In Indonesia, the data obtained shows that the total amount of zakat on shares collected in 2013-2014 only amounted to Rp 2,326,066 (PPID BAZNAS, 2017). While the potential of zakat on shares that have been calculated on the basis of the stock market capitalization of ISSI in April 2017 is about 88 trillion, assuming the whole its shareholders are moslem. The assumption is made considering the number of Indonesian investors currently reaches 600.000 
investors and most of them are moslems. So, moslem investors will certainly take shares that have been categorized as sharia or halal shares in ISSI. If zakat on shares collection is optimized, it would be a great source to be distributed on the eight ashnaf mustahik (recipient groups). Hence this study aims to identify various issues on the collection of zakat on shares, then formulate solutions and strategies in order to increase its collection.

\section{Literature Reviews}

Committee of Islamic Jurisprudence, Organization of Islamic Cooperation, Jeddah, has issued fatwa about Zakat on the Company's Assets in the $4^{\text {th }}$ meeting on $6-11$ February $\left.1988 ; 1\right)$ Shares of the company shall be zoned by shareholders. Companies may act as shareholder representatives to distribute zakat on their behalf; 2) The managerial board may distribute the zakat of the company's shares as a concrete legal subject to pay its zakat, meaning that all shares in a particular company are considered to be a property of a person; 3) If the company does not pay zakat on its shares, the shareholders are obliged to pay zakat on their respective shares. If the shareholder obtains information about the payment of his zakat on the company, his zakat obligation has been completed in accordance with the proper procedure. If the shareholder does not get the information, the shareholder's intention, if his intention when depositing a share only to obtain the annual income from the deposit, he pays his zakat on the basis of zakat exploitation, amounting to $2.5 \%$ of profit (out of capital) with taking account of the terms of receipt of such profits and other conditions and barriers. If the shareholder deposits his capital for the purpose of trade, he shall pay his zakat on the basis of trade capital, he shall pay $2.5 \%$ of capital and profits after sufficient haul whose value is calculated on the basis of current market prices or the determination of an expert; 4) When a shareholder sells his shares in the middle of a haul, he or she is required to combine the share price with his other assets, then pay his zakat as well, when the haul is perfect. The buyer is required to pay the zakat on the newly purchased shares in accordance with the above provisions. 
Some studies discusssed the issue of zakat on shares in the perspective of Islamic jurisprudence. Mawar and Edy (2015) argued that the whole Islamic scholars stated the obligatory to pay zakat on shares when it has reached nishab, haul (one year) and other provisions. Nurjanah (2011) explored the perspective of Yusuf Qardhawi on this matter. She found that Qardhawi differentiate the amount of zakat on shares for manufacturing firms and trading firms. The former is treated as farmers that should pay either $5 \%$ or $10 \%$, while the latter is regarded as trader that only pay zakat for $2.5 \%$.

Meanwhile, Rahman (2015) emphasized the need to do a screening process to find the sharia compliant shares. He also proposed the mechanism to clean the shares which is indicated as haram. In regards to zakat on shares, he explored the two mechanisms to calcuate zakat on shares.

Islahi and Obaidillah (2004), Hamat et al. (2017) studied the calculation of zakat on shares. Islahi and Obaidillah (2004) proposed average price of shares to be used as the best estimation to calculate the zakatable amount of shares. Hamat et al. (2017) differentiated the amount of zakat based on the purpose of holding shares. The different intention also determines the shares zakat accounting method.

Mujiatun (2016) studied the implementation of zakat on the profession in the Medan city. It is found that the government cut $2.5 \%$ of employees' salary every month, and then channeled it to the mustahiq. Some problems have been identified: 1) The minimum professional workers, 2) The lack of trust from muzakki, 3) Muzakki distribute the zakat to the mustahiq directly, 4) Lack of trust to pay zakat to the zakat institution, 5) No sanction for those who do not pay, 6) Lack of socialization, non-IT based management, 7) Some points of disagreement in fiqh, 8) No regional regulation on zakat.

Aristoni and Abdullah (2015) emphasized the need to broader the object of zakat including to shares. Paizin (2014) explored some strategies to improve zakat collection in wilayah persekutuan Malaysia: 1) Campaign in the various media, 2) Lecture, taklim and seminar, 3) The use of new media: social network. Meanwhile, Hayati (2012) stressed the important of srogn cooperation between 
governments, islamic scholars and society to optimize zakat in poverty eradication.

Those afformentioned researchs have not discussed spesifically on the issue of zakat on shares collection which is still low. Discussion on zakat shares is still limited to its legality and how the mechanism to calculate it. Therefore, this research is utilizing Analytic Network Process to identify the problems and propose some solutions and strategies to increase the performance of zakat on shares collection.

\section{Method}

The main source of data used in this research comes from empirical indepth interviews and individual, qualitative interviews, with experts and practitioners to comprehensively understand the problem using an openended questionnaire and a standard pairwise comparison questionnaire. Interviews between interviewer and informant are conducted face to face. The interview transcripts used are to be based upon no less than one hour of interviewing time in order to address the problems being studied. A second meeting (interview) with experts and practitioners is required to synthesise the problems and create a priority scale. In this step, the interviewer uses a pairwise questionnaire to obtain the ratio scale of the problems based upon the model discussed in the first step of the interview.

Secondary date is obtained through literatures and informations from the official website from some institutions namely BAZNAS, BEI (Indonesian Stock Exchange), ministry of religious affairs, and etc.

Seven experts in zakat on shares have been selected to be the respondents of this research. Those experts are from the Sharia Advisory Boards of Indonesian Ulama Council (DSN-MUI), lecturers, practitioners in the securities industry, regulators from BAZNAS and Indonesian Exchange Stocks.

ANP is a new approach in the decision making process that provides a general framework in treating decisions without making any assumptions about the independence of elements in the higher level from elements in the 
lower level or about the independence of elements within the same level. Moreover, ANP uses a network without having to determine levels as in the hierarchy used in the Analytic Hierarchy Process (AHP), which is a starting point of ANP. ANP is chosen because of its capability to prioritise the elements in a more stable way than AHP does. ANP also uses more appropriate tools for a complex model, as well as the model obtained in this paper. This paper attempts to explore the problems that occur in collecting cash waqf. In addition, this paper also aims to identify the solutions and strategies needed to enhance the collection of cash waqf in Indonesia. Therefore, in order to fulfil the purpose of this research, ANP is a more appropriate methodology than AHP.

ANP has relatively simple axioms which carefully restrict the scope of a problem: 1) Reciprocal. This axiom requires that if $\mathrm{PC}(\mathrm{EA}, \mathrm{EB})$ is a paired comparison of elements $\mathrm{A}$ and $\mathrm{B}$ with respect to their parent, element $\mathrm{C}$, representing how many times more element A possesses a property than does element $\mathrm{B}$, then $\mathrm{PC}(\mathrm{EB}, \mathrm{EA})=1 / \mathrm{PC}(\mathrm{EA}, \mathrm{EB})$. For instance, if $\mathrm{A}$ is four times larger than $B$, then $B$ is one quarter as large as A; 2) Homogeneity. This axiom states that the elements being compared should not differ by too much, else there will tend to be larger errors in judgement. The verbal scale of ANP ranges from one to nine, or about an order of magnitude (see table 1); 3) This axiom states that individuals who have reasons for their beliefs should make sure that their ideas are adequately represented for the outcome to match these expectations.

Table 1. Comparison of Verbal and Numeric Scales of ANP

\begin{tabular}{cc}
\hline Definition & Intensity of Importance \\
\hline Equal importance & 1 \\
Weak & 2 \\
Moderate importance & 3 \\
Moderate plus & 4 \\
Strong importance & 5 \\
Strong plus & 6 \\
Very strong or demonstrated importance & 7 \\
Very, very strong & 8 \\
Extreme importance & 9 \\
\hline
\end{tabular}


TIFBR | Tazkia Islamic Finance and Business Review

The research steps of ANP are explained by the following figure:

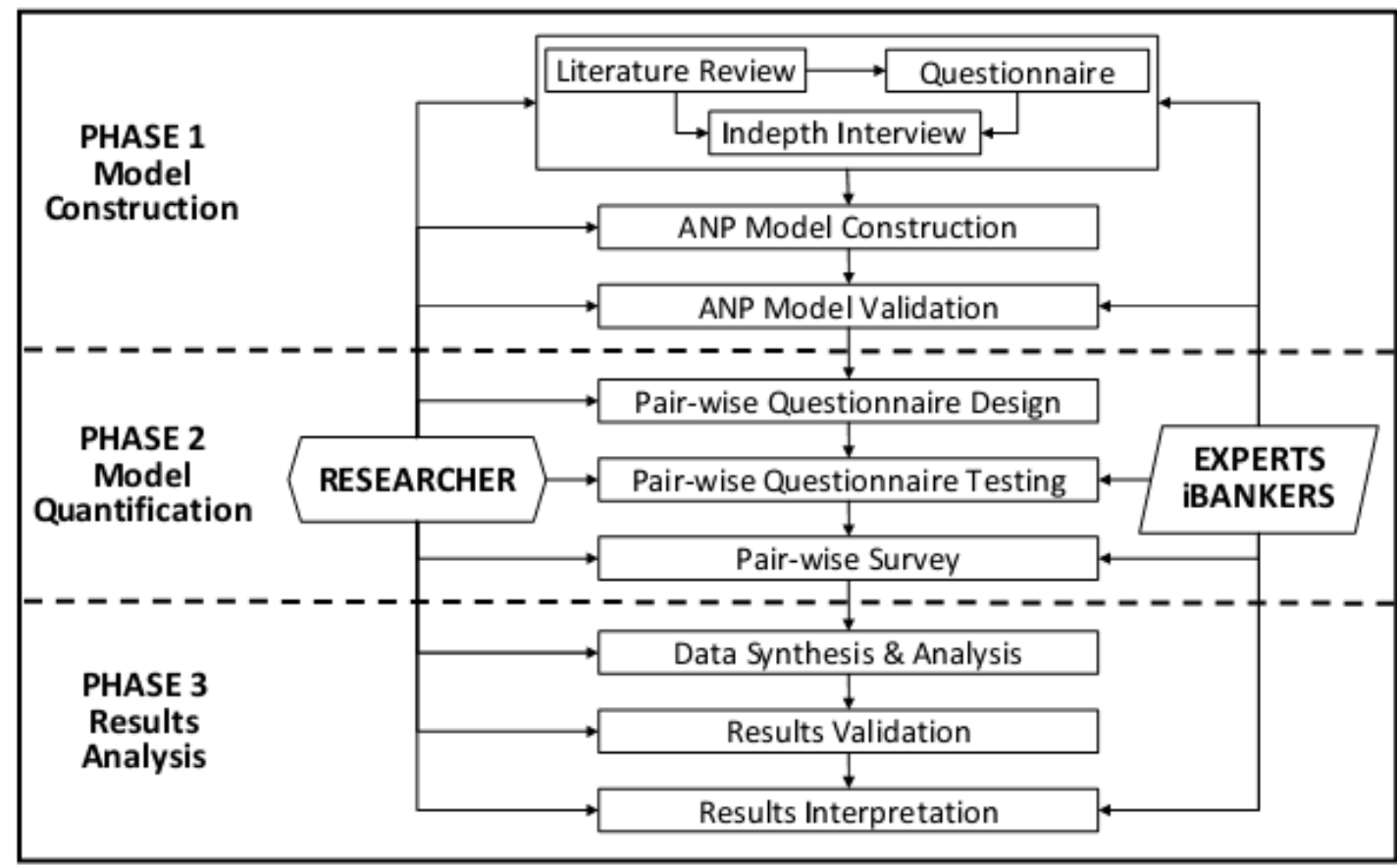

Figure 1. Steps of ANP Research

Source: Ascarya, 2011

According to Ascarya (2011), the steps of ANP research are as follows: 1) Model construction; model construction is carried out using a decomposition technique that organises the structure of the research problem to serve the understanding of the complexity of the issue (Saaty and Vargas, 2006). Model construction is obtained from studying literatures regarding to cash waqf problems in Indonesia and strengthened by in-depth interview to some waqf experts; 2) Model quantification; pairwise comparison is used in order to quantify the elements in each cluster. ANP provides a scientific method of using comparisons through measurement to reach a decision which is structured as a network with dependence and feedback. Supermatrix is mathematical approach used to measure the eigenvalue of the element in a cluster; 3) Synthesis and analysis; inconsistency for a judgement matrix can be computed as a function of its maximum eigenvalue and the order $n$ of the matrix. The consistency index is a measure of deviation from the consistency of A, denoted by $\mu$. 
TIFBR | Tazkia Islamic Finance and Business Review

The formula is:

$$
\mu=\frac{\lambda \max -n}{n-1}
$$

Where:

$\mu=$ consistency index; $\lambda_{\max }=$ maximum eigenvalue of matrix $\mathrm{A}$; and $n=$ order of matrix A.

The consistency index is used to validate the eigenvalue calculation in model quantification, while rater agreement is used to measure the agreement among raters in assessing the elements in one cluster. In ANP, judges refer to respondents, which are the experts in the area being studied. Kendall's W statistic is used, where $0 \leq W \leq 1 ; W=1$ occurs when all respondents are in total agreement (Legendre, 2005).

In order to obtain the aggregate value among respondents, a geometric mean was used, which is calculated as follows:

$$
G M k=\sqrt[n]{(R 1 * R 2 * \ldots * R n)}
$$

Where, $G M=$ geometric mean; $R=$ judgement of individual respondent; $n=$ number of respondents; and $k=$ number of pairwise comparisons.

\section{Result and Discussion}

\section{Problems Decomposition}

This research identifies problems from the three stakeholders: Zakat institution (OPZ), Securities Institution, and muzakki.

There are three main problems faced by zakat institutions in collecting zakat on shares: 1) Having no data on the amount of muzakki's shares (Kriswitaluri, 2017); 2) No special unit dedicated to manage zakat on shares. The small number of 'amil does not allow zakat institutions to manage zakat based on the objects and types of zakat (Qorina and Tanjung, 2015); 3) The absence of government enforcement. In consequence, some people do not pay zakat and some of them do pay zakat but not through legal zakat institutions. They prefer to distribute it directly to the mustahiq. (Kriswitaluri, 2017) 
There are also three main problems faced by securities institutions: 1) The low number of sharia investors, those who utilize Sharia Online Trading System (SOTS) (Kriswitaluri, 2017). The system was introduced in 2011. According to BEI, the number of sharia investors is about $2.7 \%$ from the total investors; 2) Having no integrated services with zakat institutions. Currently, the cooperation between zakat institutions and securities institution has not been made (Sutrisna, 2017); 3) Lack of Competent Human Resources who understand zakat. As a result, securities institutions do not educate their investors about zakat on shares.

Three main problems of muzakki are: 1) Lack of awareness to perform zakat on shares. Awareness is the main driver for someone to perform the obligation of zakat. To nurture awareness, sometimes, enforcement is required in the beginning (Zaenal, 2017); 2) No reminder about the haul. The behaviour of investors to make profits from the trading on shares causes them not knowing/aware when the haul is (Edi, 2017); 3) the lack of understanding of the share holders about zakat on shares. It is due to the weak education and socialization about zakat, especially zakat on shares.

\section{Solutions Decomposition}

Based on the problems decomposition, some solutions are proposed which are as follows: There are threes solutions proposed for zakat institution: 1) Making agreements with securities institution as they have the data of the moslem investors; 2) Establishing a special unit dedicated to zakat on shares (Zaenal, 2017); 3) Given an authority to force zakat payment (Edi, 2017).

There are three solutions proposed for securities institutions: 1) Intiatiating a contract with the moslem investors to pay the zakat on their shares before they open the account, stipulated in the registration form (Mukhlisin, 2017); 2) Providing integrated services with zakat institutions (Siswanto, 2017); 3) Installing zakat calculation application in the SOTS as this may solve the lack of understanding of the securities staff. 
TIFBR | Tazkia Islamic Finance and Business Review

Volume 12(2), 2018

There are three solutions proposed for muzakki: 1) Increasing the awareness to pay zakat on shares; 2) Having zakat consultant for those who are already aware to the zakat but need more education and counseling; 3) More massive education and socialization about zakat on shares by the government, Moslem Scholars, Islamic organizations and zakat institutions (Hayati, 2012).

\section{Strategies Decomposition}

Some strategies to optimize the collection of zakat on shares have been identified, they are: 1) Campaign in television as an effective media (Mukhlisin, 2017); 2) supportive regulation from authorities such as Indonesian Stock Exchange, Financial Service Authorities and Ministry of finance (Siswanto, 2017 and Sutrisna, 2017); 3) Direct deduction for zakat on shares by the securities instituions similar to the payroll system on the savings and salary of muzakki (Coryna and Tanjung, 2015).

To analyze the results, the survey was conducted to 7 respondents, where the respondents are experts in charge of zakat and stock and consists of academics, practitioners and regulators. Questionnaire as the main tool in the respondents is the result of the literature, indepth interview of some experts. After that, the results are then divided according to the criteria aspects, namely aspects of problems, solutions and strategies from the combined assessment of all respondents. The results of the processing is the result of the calculation of the average value (Geometric Mean) and the value of the agreement (Rater Agreement) between the groups of respondents. With these two values, the writer will be able to determine the order of priority of all aspects of research. Furthermore, the following explains the overall results of ANP on the optimization strategy of stock zakat collection in Indonesia.

\section{Rater Agreement on Problems}

Overall, from all respondents' ratings it is known that the level of agreement is $\mathrm{W}=0.18$, where the respondents consider that the main problem in optimizing the zakat stock collection is the muzakki problem (0.32). This is also expressed by some experts such as Zaenal (2017) who said that when 
muzakki has had the awareness to perform zakat on shares then the future will become easier. Similarly, Kriswitaluri (2017) stressed that the core of the solution of the optimization of zakat shares is in the aspect of muzakki.

From the perspective of each respondent, the main problems or constraints of optimizing the collection of zakat shares vary from one to the other based on every aspect of the problem (see Appendix A).

Respondents from securities tend to see a major problem in securities, whereas respondents from OPZ tend to see major problems with OPZ and/or muzakki. While the respondents who come from academics, almost equate the priority of all these problems. The different assessments from each expert's background make the rater agreement level smaller.

The graph below shows the priority issues of the cluster problems consisting of OPZ, securities and muzakki clusters. Then, to see the contribution of each element to the priority of the problem used limiting priorities so that it can avoid the stochasticity problem in supermatriks ANP (Saaty and Vargas, 2006). Here's the contribution of each element to every aspect of the problem:

1) Lack of understanding of the share holders about zakat on shares.

2) No reminder about the haul.

3) Lack of awareness to perform zakat on shares.

1) Lack of Competent Human Resources who understand Zakat

2) Having no integrated services with zakat institutions.

3) The low number of Shariah investors

1) The absence of government enforcement.

2) no special unit dedicated to manage zakat on shares.

3) having no data on the amount of Muzakki's shares

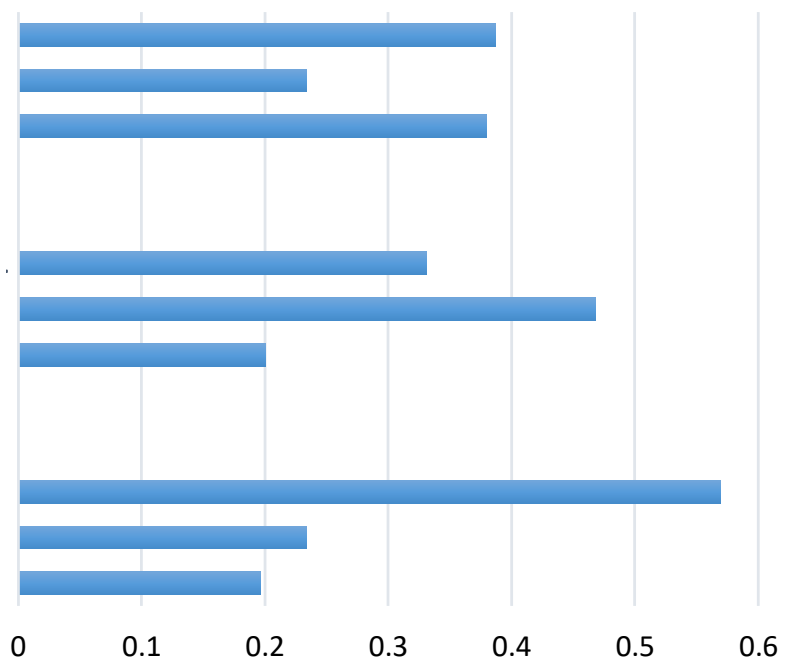

Figure 2. Priority Elements of Problems Cluster

According to experts, the main priority of the OPZ problem is the absence of enforcement from the government (0.56). BAZNAS as a State 
institution works through the rules of the state, as well as other OPZ coordinated under BAZNAS. Thus, if it has not been specifically authorized by the OPZ from the government, it is difficult for the OPZ to make a strategy (Zaenal, 2017). Moreover, the top priority for securities issues is the absence of integrated services with OPZ (0.46). Securities as the only party managing the shares can not optimize the collection of zakat if there is no cooperation with OPZ. (Sutrisna, 2017). Furthermore, the experts argued that the main priority of muzakki's problem is the lack of understanding of shareholders concerning zakat on stock (0.38). The second priority problem is awareness muzakki to perform zakat on shares (0.37) and the third priority is no reminder haul to perform zakat shares $(0.23)$.

Thus, the overall result based on the combined value of Geometric Mean can be concluded that the priority of problems or constraints in optimizing the collection of zakat shares in Indonesia respectively is the issue there is no authority or enforcement from the government (0.56) from the OPZ cluster, unavailibiliy of integrated services with OPZ (0.46) from the securities cluster, and then the lack of understanding of shareholders regarding the zakat on stock (0.38) from muzakki cluster.

\section{Rater Agreement on Solutions}

The result of rater agreement from the whole expert respondents on the solution has an agreement value of $W=0.17$. With the value of the very low agreement shows that of all respondents have different opinions on the aspects of the solution. That's because the background difference of each respondent who tends to see with subjective.

In overall, respondents argued that securities solution is an important solution and effective role in overcoming the problem of optimization of stock zakat accumulation in Indonesia, so that can encourage increase zakat stock collecting. Respondents consider that the first time to be prepared is the securities, as stated by Zaenal (2017), then followed by muzakki, in line with the result of a muzakki solution agreement which differs only slightly from the 
securities solution agreement. Securities solution factors in the form of contracts at the beginning, provided services that are integrated with OPZ and make zakat counting application on SOTS, is a comprehensive solution that can produce the realization of the optimization of stock zakat accumulation in Indonesia. The existence of the contract at the beginning is required as a path opener between potential moslem investors as muzakki zakat shares. While the provision of integrated services with OPZ becomes the bridge of zakat distribution of shares by securities so that zakat funds can be managed properly by OPZ. Then it is also facilitated by zakat system application support on SOTS.

Next is a muzakki solution whose value differs only slightly from securities solutions, indicating that both securities and muzakki are considered important by the respondents. If the understanding and awareness of muzakki is good enough, supported by the readiness of the securities, then OPZ more easily accommodate and manage the funds. Thus, the respondents had very little agreement on OPZ's solution of only 0.25 .

In the solution cluster, to see the contribution and priority of each aspect of OPZ solution, securities and muzakki then use the limiting priorities value of each aspect so as to avoid stochasticity in supermatriks ANP (Saaty and Vargas, 2006). The more clearly the contribution and priority of each aspect of each solution cluster can be seen in the graphic below:

1) More massive education and socialization

2) Having zakat consultant

3) Increasing the awareness to pay zakat on shares,

1) Installing zakat calculation application in the SOTS

2) Providing integrated services with OPZ

3) Intiatiating a contract with the moslem investors to pay the zakat on their shares

1) Given an authority to force zakat payment

2) Establishing a special unit dedicated to zakat on shares

3) Making agreements with securities institution

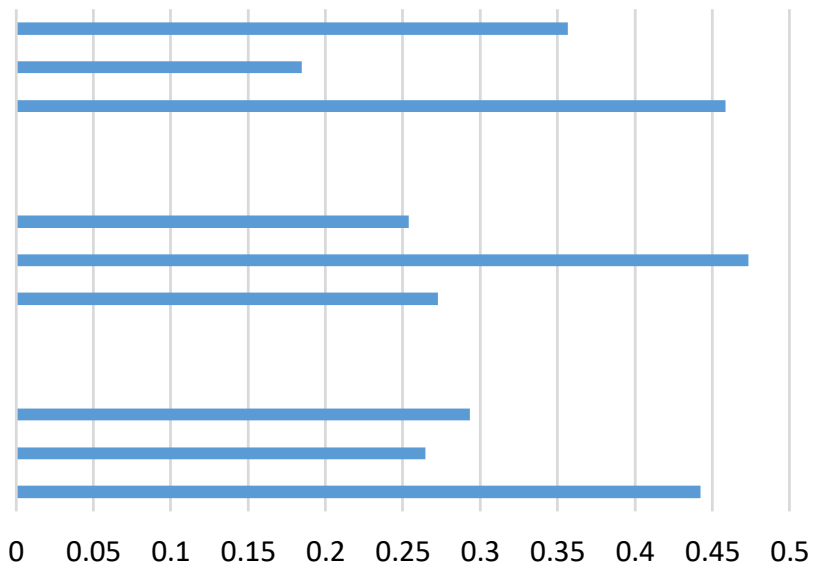

Figure 3. Priority Elements of Solutions Clusters 
The result of the opinion of all respondents, there are three solution priorities in overcoming the problem or constraint of optimization of stock zakat accumulation in Indonesia. The solution is to provide integrated services with OPZ (0.47) from the securities cluster, the awareness of performing zakat shares (0.45) from the muzakki cluster and the cooperation with securities (0.44) of the OPZ cluster.

\section{Rater Agreement on Strategies}

The result of the agreement value of the policy strategy in the opinion of all respondents is $W=0.6$. This figure is the greatest deal value among the three other major aspects of the whole, namely the problem $(\mathrm{W}=0.18)$ and the solution $(\mathrm{W}=0.17)$. This shows the high agreement of respondents and the small variation of respondents' opinion in looking at the right strategy for optimizing the collection of zakat shares in Indonesia, although the background of each respondent is different. Overall, the overall opinion of the respondents indicated that the main priority was the regulatory approach strategy (0.42), followed by the direct cut zakat share strategy (0.37) and the campaign strategy on television (0.2). The overall priority trend of respondents in the strategy cluster can be seen in the appendix 9 .

The value of the overall agreement of the respondents is large enough to mean that these strategies are possible to run. The need for a clear policy that governs the process flow of zakat shares between securities and muzakki. Then also needed a direct cutting strategy as the adoption of the strategy of accumulating zakat savings and zakat profession.

The biggest trigger of the drivers of the external changes of zakat institutions is the increased awareness of obligatory zakat society and also the regulatory changes of the government (Coryna and Tanjung, 2015).

The priority of optimizing strategy of stock zakat accumulation in Indonesia is seen from the geometric mean result described in the graph picture below: 
TIFBR | Tazkia Islamic Finance and Business Review

Volume 12(2), 2018

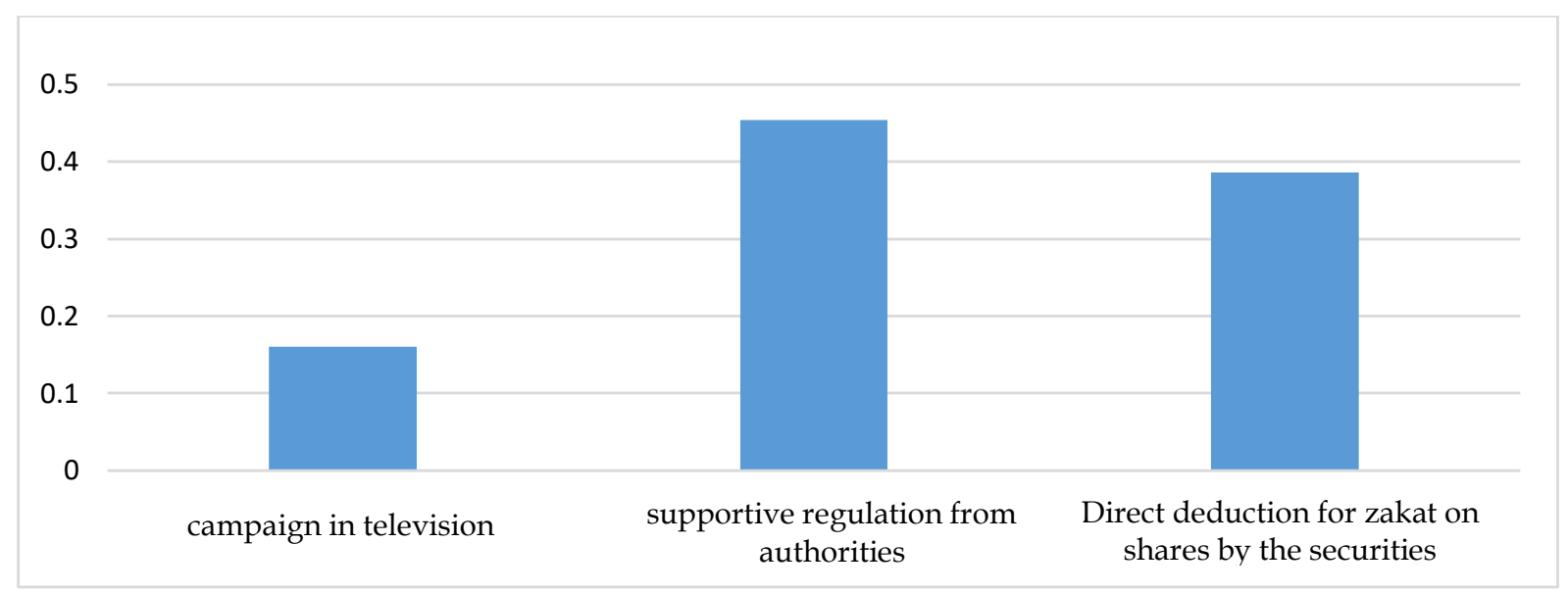

Figure 4. Priority Elements of Strategies Cluster

In the opinion of the respondents as a whole $(W=0.6)$, the main priority on the policy strategy is the regulatory approach of the BEI to the securities (0.45), followed by the direct cuts of zakat shares by securities (0.38) and the last is the aspect of campaign strategy on television (0.16).

The main priority in the optimization strategy of stock zakat accumulation in Indonesia is the strategy aspect of the approach of reegulation. It is as mentioned before, that the importance of a regulation that regulates the flow of cooperation between the securities as the party that manages the shares and the OPZ as the party that manages the zakat. Then on the direct cut strategy of zakat shares by securities will facilitate the collection as well as a solution to the lack of competence of HR due to direct cutting system using technology and applications so more accurate and efficient. While the campaign strategy on television, according Kriswitaluri (2017) will cost greater than the amount of zakat funds will be collected.

\section{Conclusion}

Based on the results of research, it can be taken several conclusions. The overall priority of the respondents is $(\mathrm{W}=0.18)$ with the value of the agreement rater or the value of the agreement of the highest is: 1) Muzakki problem; 2) OPZ issues; and 3) Securities issues. While the priority of problem nodes is: 1) No enforcement from the government; 2) There is no integrated service with OPZ; and 3) Lack of understanding of shareholders regarding zakat shares. 
The priority of solutions agreed by all respondents $(\mathrm{W}=0.17)$ in sequence are: 1) Securities solution; 2) Muzakki solution; and 3) OPZ solution. With the priority of solution nodes are: 1) Provided services integrated with OPZ; 2) The existence of cooperation with securities; and 3) The existence of awareness to issue zakat shares.

In addition, the priority of the overall strategy aspect $(W=0.6)$ is: 1$)$ The regulatory approach of BEI to the securities; 2) Direct deductions of zakat on shares; and 3) Campaign on television.

Therefore, it is recommended for OPZ to develop its human resources and to increase cooperation between institutions, especially with securities. Moreover, the government or regulator should provide a policy to enforce zakat payment as well as to have more massive education.

\section{References}

Aristoni, and Abdullah, J. (2015). Reformulasi Harta Sebagai Sumber Zakat dalam Perspektif Ulama Kontemporer. Jurnal ZISWAF, Vol. 2.

Ascarya. (2011). The Persistence of Low Profit and Loss Sharing Financing in Islamic Banking: The Case of Indonesia. Review of Indonesian Economic and Business Studies, Vol. 1. Lipi Economic Research Center.

Coryna, I. A., and Tanjung, H. (2015). Formulasi Strategi Penghimpunan Zakat oleh Badan Amil Zakat Nasional (BAZNAS). Jurnal Al-Muzara'ah, Vol. 3 (2).

Hayati, M. (2012). Peran Pemerintah dan Ulama dalam Pengelolaan Zakat dalam Rangka Usaha Penanggulangan Kemiskinan dan Peningkatan Pendidikan di Indonesia. Asas: Jurnal Hukum dan Ekonomi Islam, Vol. 4 (2).

Hamat, Z., Endut, W.A., Hanapi, M. S. (2017). Shares Zakah Accounting in Malaysia: Fatawa, Manual and Practices. International Journal of Academic Research in Business and Social Sciences, Vol. 7 (2).

Islahi, A. A., and Obaidullah, M. (2004). Zakah On Stocks: Some Unsettled Issues. Journal of Islamic Economics Journal, Vol. 17 (2).

Islamic Fiqh Academy. (1985-2000). Resolutions and Recommendations of The Council of The Islamic Figh Academy. Jeddah: Islamic Development Bank Islamic Research and Training Institute Jeddah.

Mujiatun, S. (2016). Analisis Pelaksanaan Zakat Profesi: Upaya Pengentasan Kemiskinan di Kota Medan. Jurnal At-Tawassuth, Vol. 1. 
TIFBR | Tazkia Islamic Finance and Business Review

Volume 12(2), 2018

Paizin, M. N. (2014). Perlaksanaan Zakat di Wilayah Persekutuan: Satu Pemerhatian Terhadap Operasi Kutipan dan Agihan Zakat. Jurnal Hadhari, Vol. 2.

Qardhawy, Y. (2002). Figh Zakat. Jakarta: Litera Antar Nusa.

Rahman, S. (2015). Ethical Investment in Stock Screening and Zakat on Stocks. Journal of Islamic Finance IIUM.

Saaty, T.L. and Vargas, L.G. (2006). Decision Making with the Analytic Network Process. Economic, Political, Social and Technological Applications with Benefits, Opportunities, Costs and Risks. Springer. RWS Publication, Pittsburgh.

Yuswohady and Kemal, E. G. (2015). 8 Wajah Kelas Menengah. Jakarta: PT. Gramedia Pustaka Utama. 


\section{Appendix}

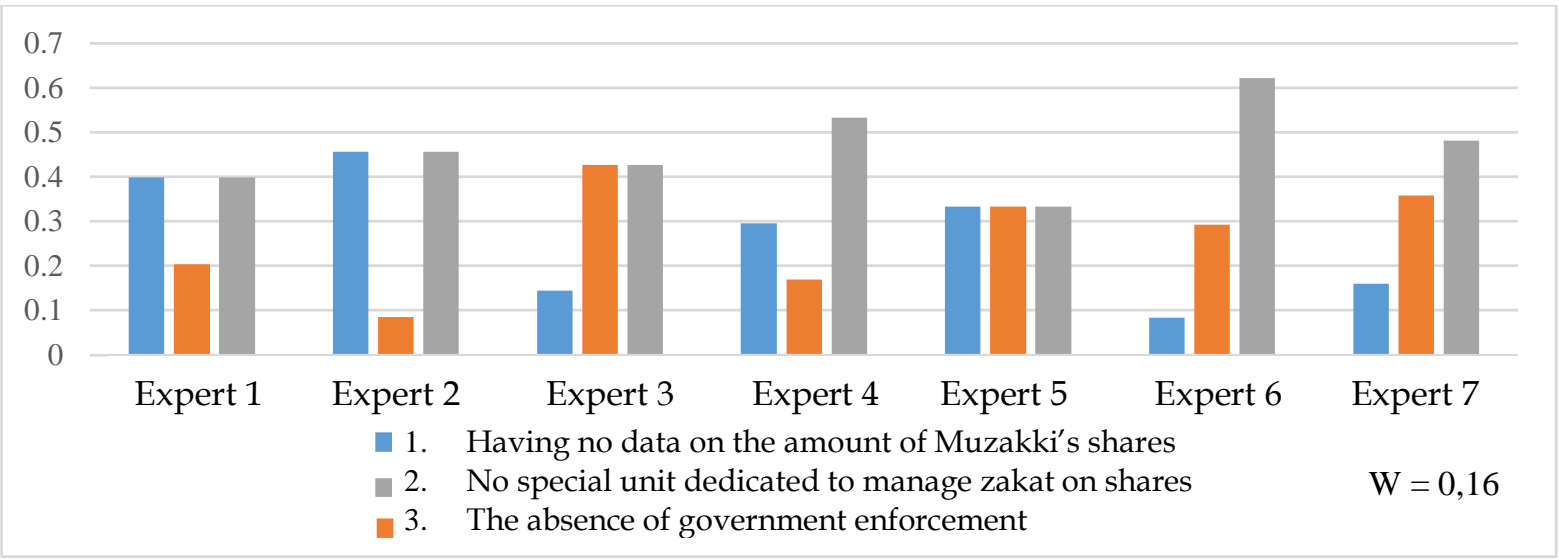

Appendix 1. Rater Agreement of Problems in OPZ

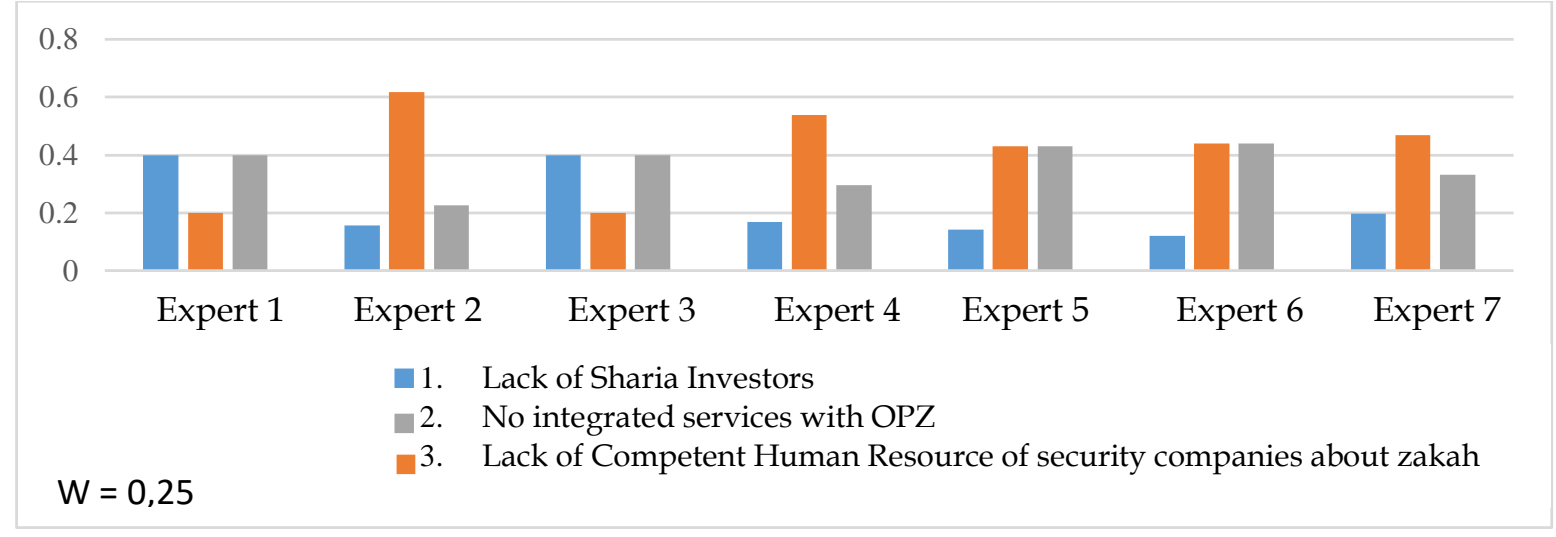

Appendix 2. Rater Agreement of Problems in Securities

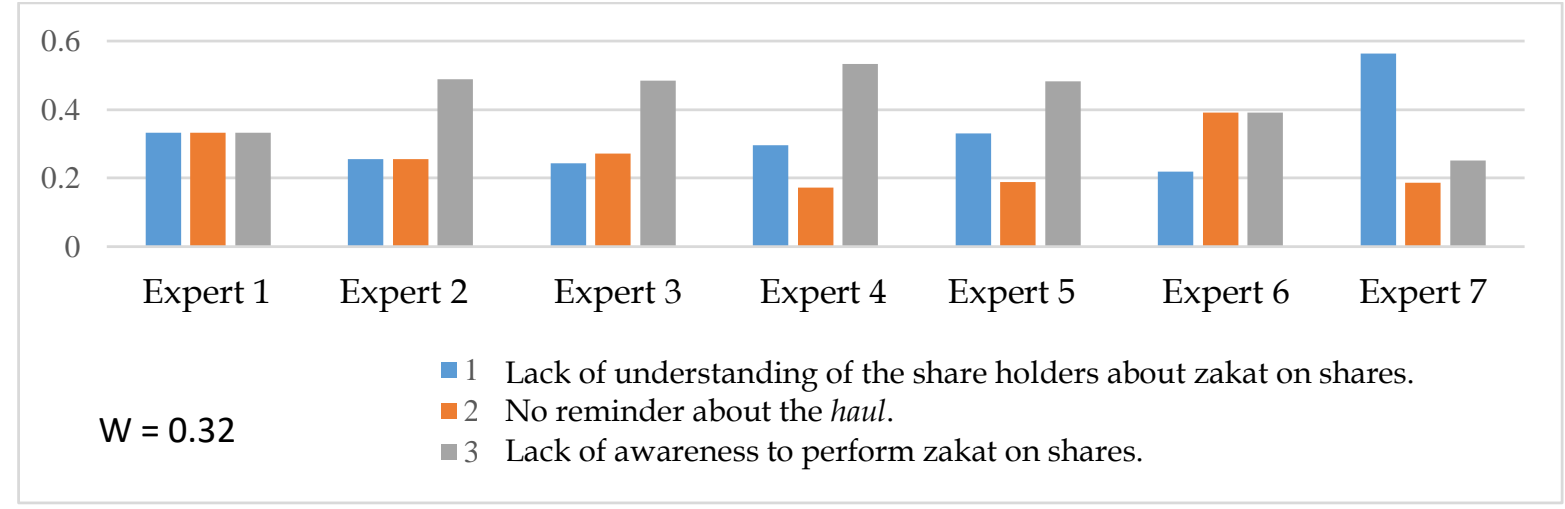

Appendix 3. Rater Agreement of Problems in Muzakki 
TIFBR | Tazkia Islamic Finance and Business Review

Volume 12(2), 2018

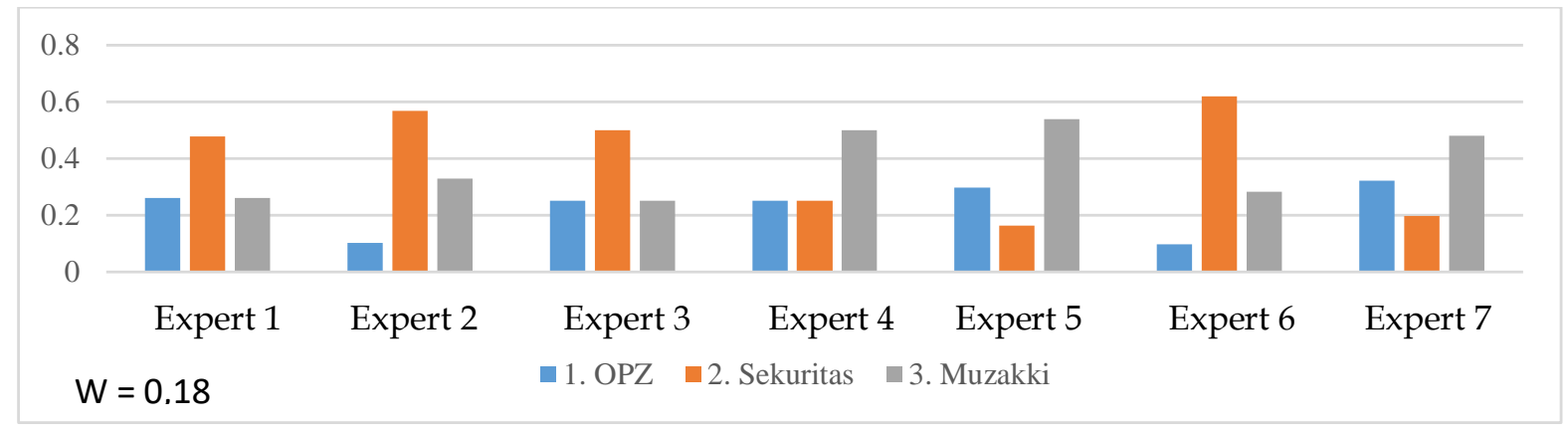

Appendix 4. Rater Agreement of Overall Problems

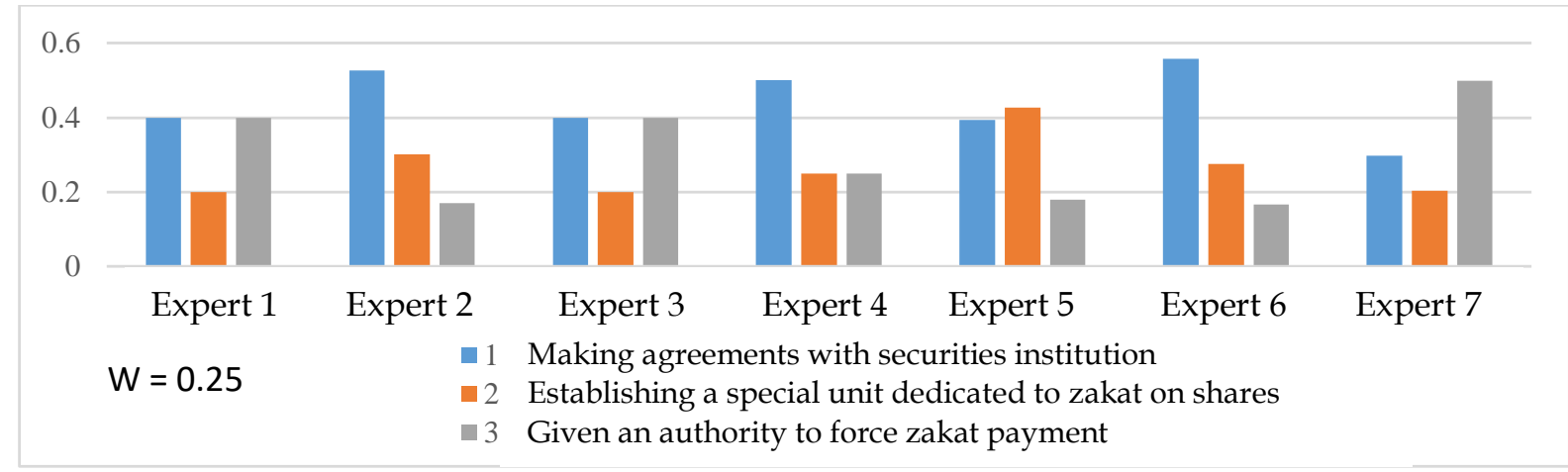

Appendix 5. Rater Agreement of Solutions for OPZ

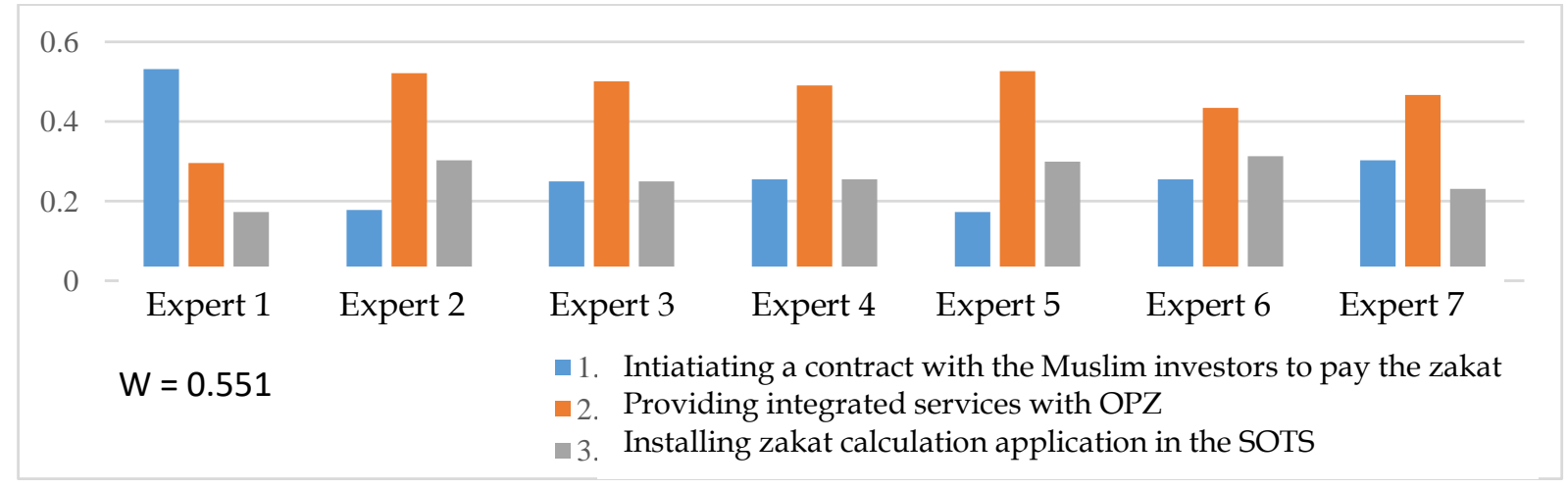

Appendix 6. Rater Agreement of Solutions for Securities 
TIFBR | Tazkia Islamic Finance and Business Review

Volume 12(2), 2018

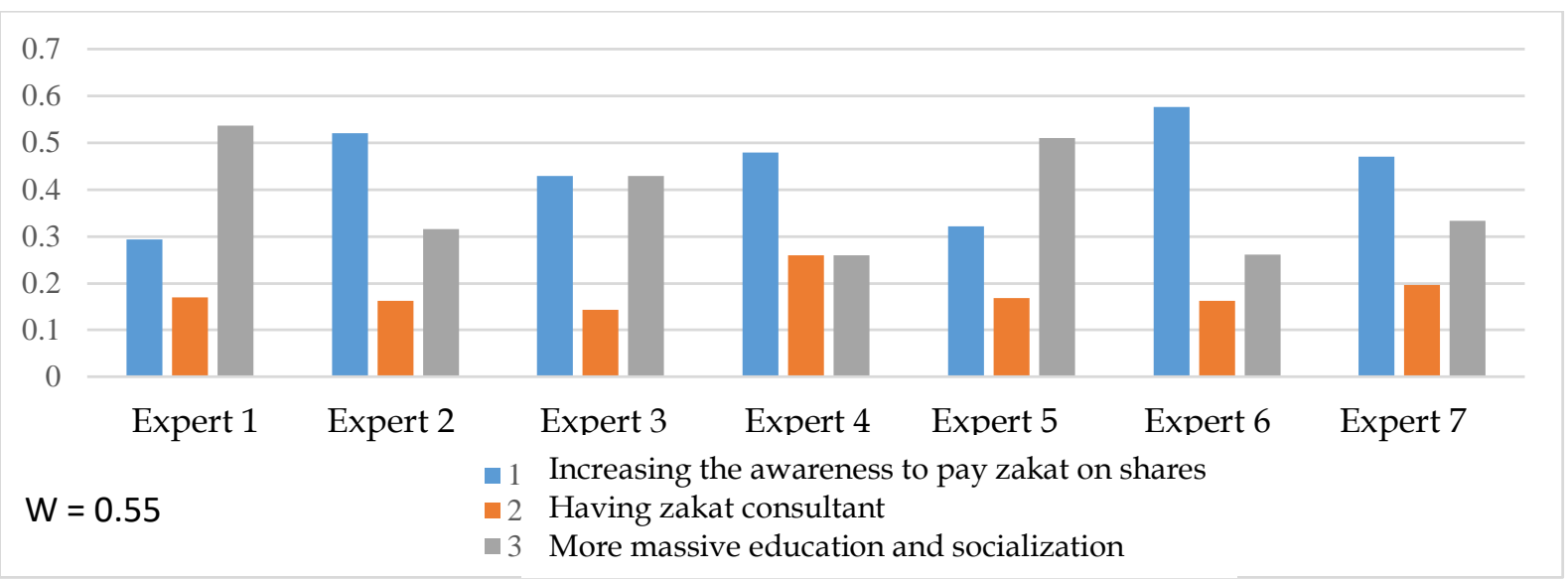

Appendix 7. Rater Agreement of Solutions for Muzakki

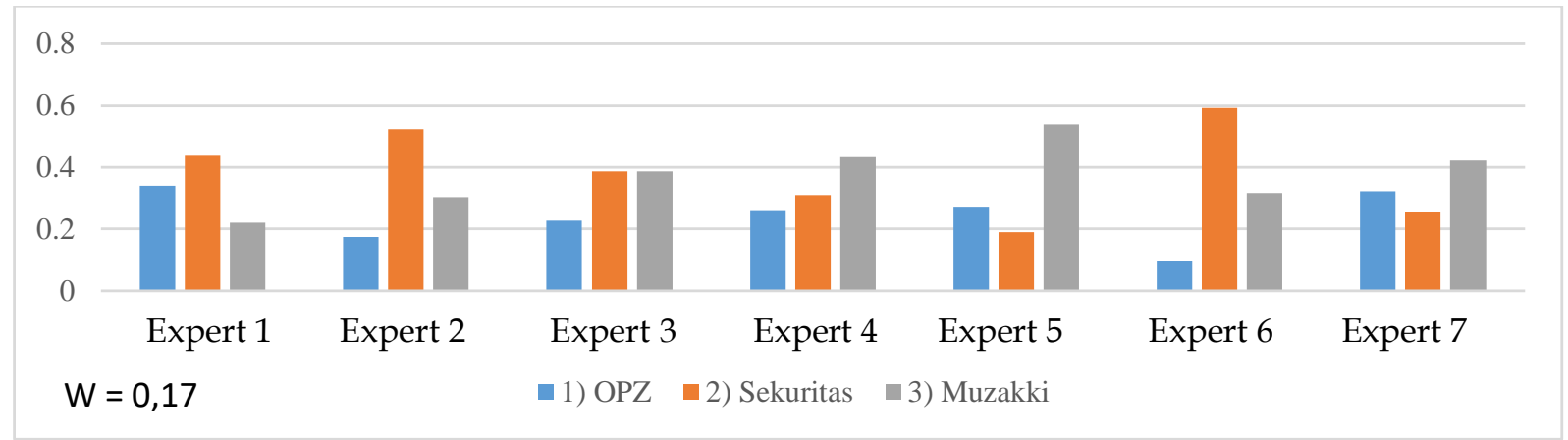

Appendix 8. Rater Agreement of Solutions for Overall

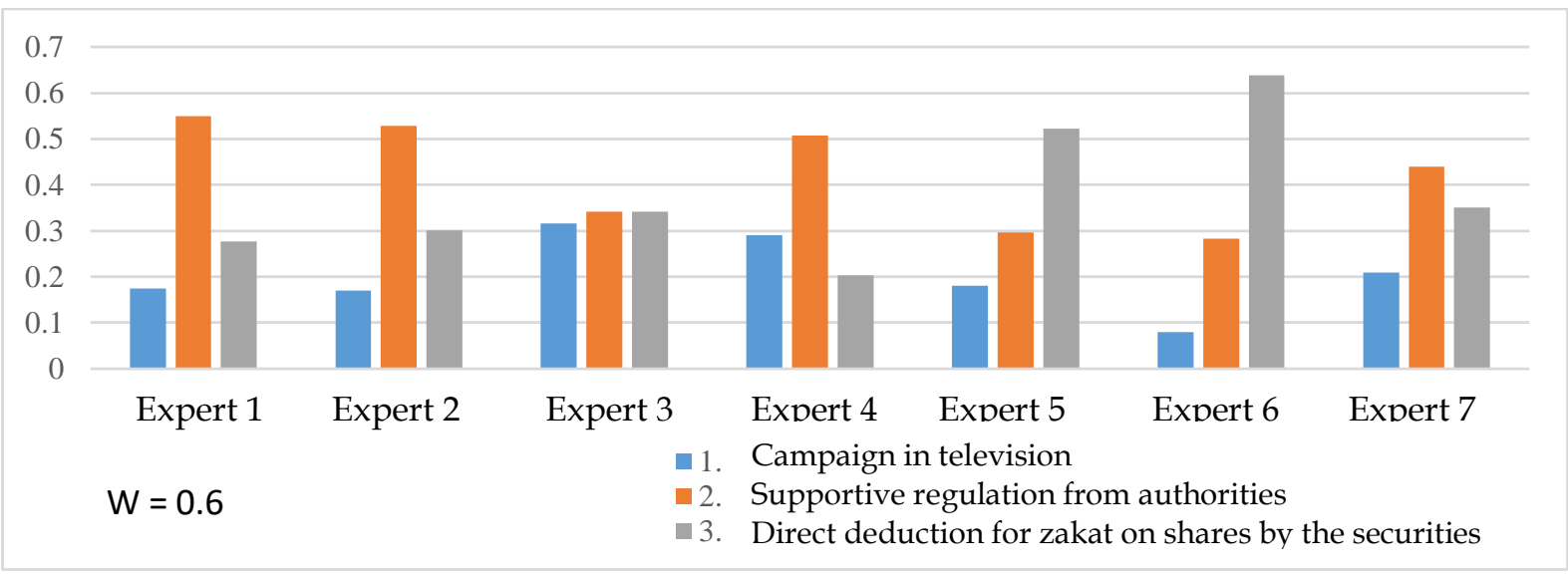

Appendix 9. Rater Agreement of Strategies 